\title{
単一モード光ファイバ用フッ化物 ガラス母材の作製技術
}

\section{1. は じめに}

フッ化物光ファイバは, $0.3 \sim 3.5 \mu \mathrm{m}$ の波長域において 石英光ファイバより低い固有伝送損失を有し，その最小値 は波長 $2.55 \mu \mathrm{m}$ で石英系の最小值の $1 / 10$ 以下に低下寸る と推定されている．このため，フッ化物ファイバは次世代 光伝送媒体の最有力候補に揚げられており，その固有損失 実現を目指してガラス系の探索やファイバ化技術の開発が 進められている。これまでに，熱安定性の高いガラスとし て $\mathrm{ZrF}_{4}, \mathrm{BaF}_{2}, \mathrm{NaF}$ を主成分とする系(1)が見いだされてい、 るが，そのガラス化には急冷が不可欠である。このような 急冷を要するフッ化物ガラスをファイバに加工する手法と して, Rotational Casting ${ }^{(2)}$, Suction Casting ${ }^{(3)}$ 等の溶融キ ヤスティング法を用いたガラス母材作製法が開発されてき た.その結果, 現在 $1 \mathrm{~dB} / \mathrm{km}$ 程度の損失值が多モードフ ァイバ(長さ〜 $100 \mathrm{~m}$ )で得られるにいたっている.

フッ化物光ファイバの媒体特性を最大限に活かすにはフ フイバを単一モード化する必要がある，単一モードファイ バの作製には二重るつぼ線引き法(4)やジャケット線引き 法(5)が検討されてきた。二重るつぼ線引き法では，ガラス 化に必要な冷却速度が得られるよらに改良されて，500 $\mathrm{m}$ 程度のファイバが作製されているが，伝送損失が報告 されるにはいたっていない、ジャケット線引き法はジャケ ットガラス管にガラス母材を挿入して一体化して線引き, 単一モード化に必要なコア径を実現する方法である。この 手法では数 $\mathrm{dB} / \mathrm{km}$ の損失值が得られているが，それらが 実現されているファイバは短く $(<30 \mathrm{~m})$ ，長尺でかつ低 損失なものは作製されていない。この手法で長尺ファイバ を得るにはコア/クラッド径比の小さい大型の母材を作製 するか, あるいは母材コアの均一細径化を図る必要があ る.

著者らは，長尺・低損失なフッ化物単一モードファイバ の作製を目的として，ジャケット線引き用の母材作製に延 伸法を適用する技術 ${ }^{(6)}$ を初めて開発した，以下，単一モー ドファイバ用フッ化物ガラス母材の作製技術とその波長

* NTT 光エレクトロニクス研究所光材料部

1) 主幹研究員 2)主任研究員

Fabrication of Fluoride Glass Preforms for SingleMode Optical Fibers; Terutoshi Kanamori, Yukio Terunuma (NTT Corporation) 1992年 1 月 31 日受理
金 森 照 寿* 照 沼 幸 雄*)
$2.5 \mu \mathrm{m}$ 帯光伝送用ファイバ作製および波長 $1.3 \mu \mathrm{m}$ 帯光 増幅用ファイバ作製への適用について述べる。

\section{2. ジャケット線引き用母材開発の方策}

フッ化物ガラスは，石英ガラスに比べ結晶化に対する熱 安定が低いため，製造には大きな制約がある，溶融キャス ティングによってガラスロッドを作製する場合，冷却速度 によって外径の大きさが制限される．現時点では $15 \mathrm{~mm}$ を越えると微結晶が析出し易くなる。 ガラスが再加熱され る場合，ガラス転移温度から $100^{\circ} \mathrm{C}$ 上では急速に結晶化 する。なお再加熱過程では一般に表面結晶化が内部のバル ク結晶化に先行する傾向がある。

ジャケット線引き用の母材は溶融キャスティングによっ て直接作製することが最善である。しかし，これまで開発 されたこの種の手法では長尺・単一モード化の可能な母材 は得られない。例えば，Rotational Casting は予熱したモ ールドにクラッドガラス融液を注入し，モールドを水平に して高速回転させながら融液を固化させ，生じた中空部に コア融液を注入する方法である.この方法では一定のコア/ クラッド径比が得られるが，上述したよらに外径の大きさ が制限され，コアの細径化も難しい。このため径比を小さ くできない. Suction Casting は予加熱したモールドの上 部開口部からクラッド融液を注入し, 続けてコア融液をク ラッド融液の上に注ぎ込む方法である。この際，クラッド 融液の固化による体積収縮によってコア融液は下方へ吸い 込まれ，コアが形成される。この方法では部分的には細径 コアが得られ，コア/クラッド径比も小さくなるが一定に はならない。また，コアガラスをジャケット用ガラス管に 挿入して一体化する方法もあるが，この手法では欠陷のな い良質なコア・クラッド界面を形成することが難しい.

そこで，溶融キャスティング母材をジャケットガラス管 に挿入して一体化して延伸する方法(ジャケット延伸)を採 用し，コアの均一細径化を図った。フッ化物ガラスでは， 延伸工程を付加することにより結晶化が一層進行すると考 えられていたが，次の方策で結晶化を抑制した（1)界面や 内部の欠陷が少なく，コア径の小さい母材を使用する. Suction Casting では界面が同時に形成され，かつ冷却速 度も高く取れるので, 得られる母材はこの条件に合らが， コアはテーパー状になって一定にならない。このため，母 材コアのテーパーをストレートに修正して，同時に細径化 
する方法(テーパー延伸法)を開発する。(2)ジャケット管に も内壁や内部の久陥の少ないがラス管を用いる。これは Rotational Casting 亿よって作製する。(3)延伸は, 再加熱 で先行する表面結晶化に注目し，これを抑制する条件を見 いだすことで最適化する。

\section{3. テーパー延伸法}

テーパ状のコアを以下に述べるょうに延伸して所定の径 の均一コアに加工した。 コア径 $D$ が次の式で表されるテ 一パ形状を有する時,

$$
D=\alpha z+\beta
$$

母材をコア先端 $(z=0)$ 部の方向へ $V_{0}$ の速度で送り, コア 径が $D_{0}$ になる位置を起点(時間 $t=0$ ) 江次示す速度 $V$ で引き取ると， $D_{0}$ の径の均一コアが得られる。

$$
V=V_{0}\left(\alpha V_{0} t / D_{0}+1\right)^{2}
$$

内径 $7 \mathrm{~mm}$ のモールドで作製した Suction Casting 母材は 円錐に近い形状のコアプロファイルを示し, 并の径は $z=12 \sim 58 \mathrm{~mm}$ で次のように近似でさた。

$$
D=0.041 z+1.1 \quad(\mathrm{~mm})
$$

この母材をテーパ延伸すれば>1.6 mm のコア径が得ら れる。それ以下細径化するには，ストレートにジャケッ 卜延伸する工程を付加する必要がある。図1亿作製したフ >イバのコア径変動を示す。コア径恃一で, $\pm 0.1 \mu \mathrm{m}$ 以内に入っていることがわかる。

\section{4. 表面結晶化の抑制}

フッ化物ガラスの表面結晶化は塺や水などの污染や傷等 が付随的な核になって加速される。このため，これらの欠 陥を徹底的涂去し, から低温・短時間で延伸できる条件 を探索するこ上によりその抑制を図った。がラス母材住研 磨紙を用いて一定の外径任研磨した後, $\mathrm{ZrOCl}_{2}$ の塩酸溶 液を用いてェッチングし，傷等の欠陥を除去した。ジャケ ット管はクリーンでドライな不活性ガス䨌囲気で作製し,

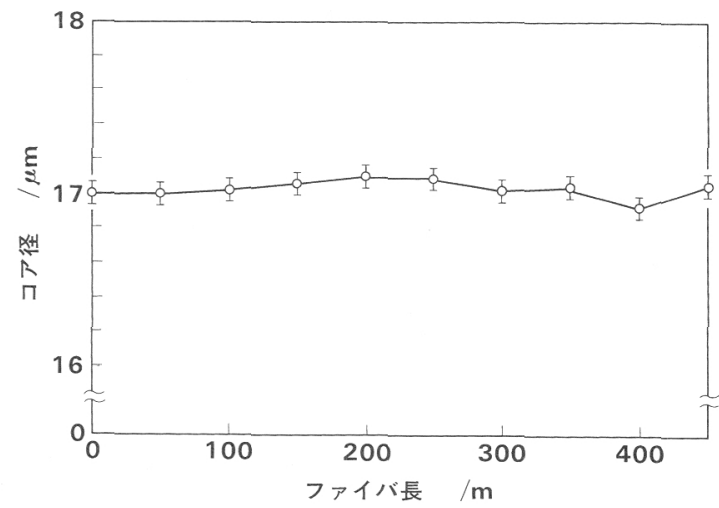

図1ファイバのコア径変動(7).

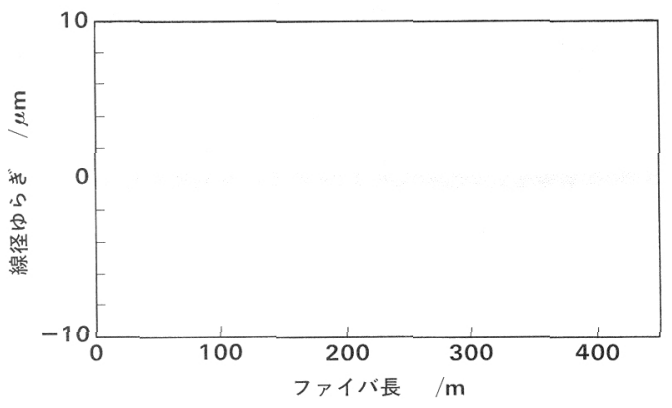

図2 ファイバの線径ゆらぎ(ファイバ線径：125 $\mu \mathrm{m})$.

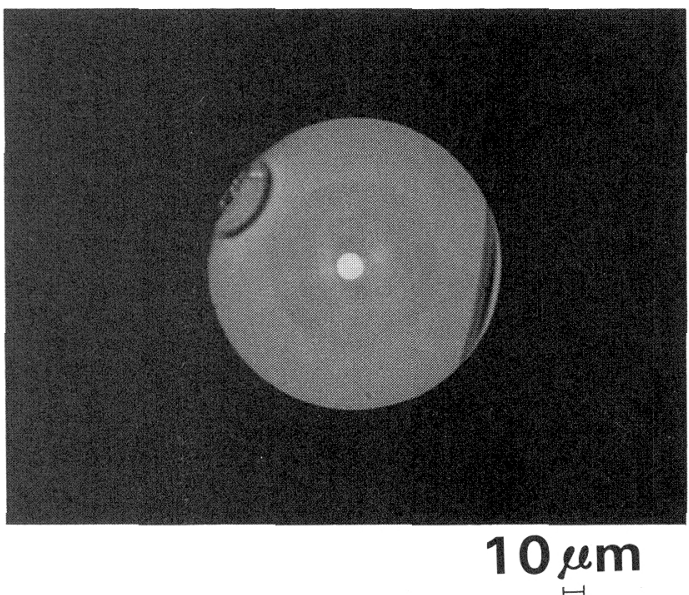

図 3 ファイバの断面写真 ${ }^{(7)}$.

さらに同様な雾囲気で母材を内部に挿入することにより， 管内壁の污染を防止した。延伸はジャケット管内を減圧 し, 不活性ガス雾团気でゾーン加熱して行った. 延伸時に 結晶化が生じる之, これは線引きの際のファイバ線径のゆ らぎや形成された界面の不整となってあらわれる。図2 線引き時の線径モニターのトレースを示す。ファイバ外径 のゆらぎ(線径ゆらぎ)が $11 \mu \mathrm{m}$ 以内に入ることから， クロンオーダーの結晶は生じていないことがかかる。つア イバの断面写真を図 3 に示す。ジャケッティングによって 形成された界面は良く整合しており，不整は見られない。

\section{5. $2.5 \mu \mathrm{m}$ 帯光伝送用単一モードファイバ}

最小損失が予想されている波長 $2.55 \mu \mathrm{m}$ で単一モード 化するには，コアとクラッド間の比屈折率差 $\Delta n を 0.3 \%$ 没設し，から線引き淀 $15 \mathrm{~mm}$ 径のジャケット管を使用 する場合，母材のコア径を $1.8 \mathrm{~mm}$ に設計する必要があ る。これは 1 回のテーパー延伸で達成できる(7)。作製し たファイバの伝送損失スペクトルを図4 亿示寸。波長 $2.15 \mu \mathrm{m}$ のピークは $\mathrm{LP}_{11}$ モードの遮断に起因しており， $2.35 \mu \mathrm{m}$ より長波長で単一モード領域に入ることがわかる. 


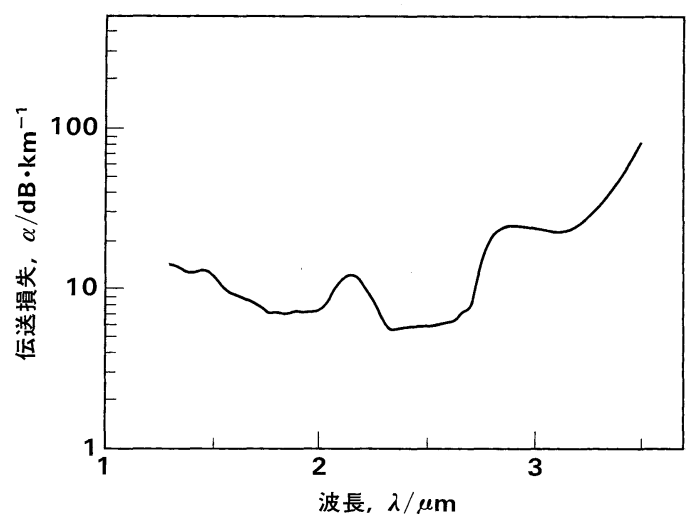

図 4 伝送損失スペクトル(コア径 : $14.5 \mu \mathrm{m}$, 外径 : $125 \mu \mathrm{m}, \Delta n: 0.3 \%$, ファイバ長 : $324 \mathrm{~m}$ ).

$2.35 \mu \mathrm{m}$ での損失值は $5.5 \mathrm{~dB} / \mathrm{km}$ である.この伝送損失 は多モードファイバで報告されている最小值より大きい が，同一長さのものと比較すると低損失である．本技術で 作製されたファイバを用いて波長 $2.55 \mu \mathrm{m}$ での伝送実験 が試みられ， $2.1 \mathrm{~km}$ スパンのコヒーレント伝送実験が達 成されている(8).

\section{6. $1.3 \mu \mathrm{m}$ 帯光増幅用単一モードファイバ}

Prをコアに添加したフッ化物光ファイバは既存の通信 波長である $1.3 \mu \mathrm{m}$ 帯用光増幅媒体として非常に注目され ている. 増幅効率を高めるには信号光と励起光をともにコ ア内に閉じ込めることが必要で, これには高 $\Delta n \cdot$ 単一モ ード化を実現しなければならない. $15 \mathrm{~mm}$ 径のジャケッ 卜管を使用した場合，波長 $1.0 \mu \mathrm{m}$ で単一モード化するに は，母材ュア径は $\Delta n$ を $0.6 \%$ と設定すると $0.5 \mathrm{~mm}, 3.7 \%$ では $0.2 \mathrm{~mm}$ に設計する必要がある。これらはストレート 延伸を 2 回加えることで実現できる. 図 5 は Prドープフ アイバの増幅スペクトルである(9). 波長 $1.31 \mu \mathrm{m}$ で 32.6 $\mathrm{dB}$ の利得が得られている.さらに, $\Delta n=3.7 \%$ のァイ バでは利得係数 $0.2 \mathrm{~dB} / \mathrm{mW}$ が達成され, レーザーダイオ ードによる光増幅の可能性が確認された ${ }^{(10)}$.

\section{7. あとがき}

本技術はフッ化物ガラスでは困難とされていた延伸法を 初めて実用的な水準まで向上させたものであり，フッ化物

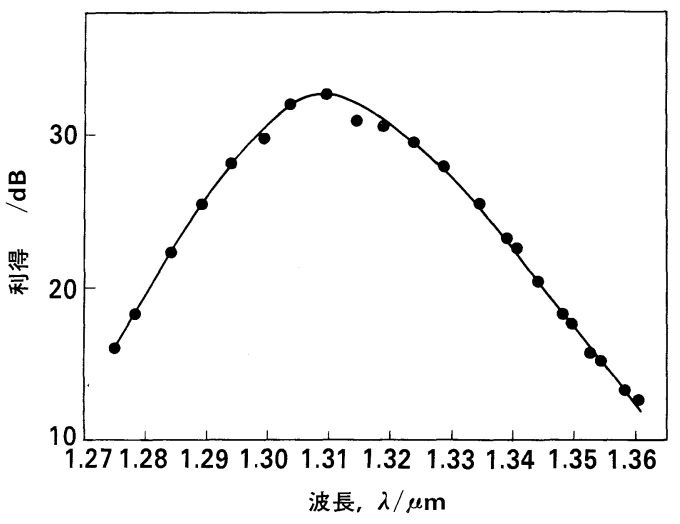

図 5 光増幅スペクトル $(\operatorname{Pr}: 500 \mathrm{ppm}$, コア径 : $3.3 \mu \mathrm{m}$, 外径 : $125 \mu \mathrm{m}, \Delta n: 0.6 \%$, ファイバ 長 : $23 \mathrm{~m}$, 励起光強度 (波長 $1.017 \mu \mathrm{m}$ ) : 925 $\mathrm{mW})^{(9)}$.

単一モードファイバの長尺化を可能にし，伝送損失值も多 モードファイバと遜色のないレベルまで低下させた，これ によって $1.3 \mu \mathrm{m}$ 帯光増幅の開発が進展した．超低損失の 実現には課題が残っているが，フッ化物ガラスで延伸法が 適用できることを示したことにより，今後の低損失化研究 での新たな手段を提供したといえる。

\section{文献}

(1) 特許：特願昭61-119049.

(2) D. C. Tran, C. F. Fisher and G. H. Sigel, Jr.: Electron. Lett., 18(1982), 657.

(3) Y. Ohishi, S. Sakaguchi and S. Takahashi: Electron. Lett., 22 (1986), 1034.

(4) H. Tokiwa, Y. Mimura, T. Nakai and O. Shinbori: Electron. Lett., 21 (1985), 1131.

( 5 ) Y. Ohishi, S. Mitachi and S. Takahashi: IEEE J. Lightwave Technol., LT-2(1984), 593.

(6) 特許: 特願平 2-134018.

（7）金森照寿, 照沼幸雄, 藤浦和夫, 及川喜良, 高橋志郎 : NTT R \& D, 39 (1990), 1353.

( 8 ) T. Komukai, Y. Miyajima, T. Kanamori and Y. Terunuma: Proc. IOOC-ECOC'91, Paris, (1991), 697.

( 9 ) Y. Ohishi, T. Kanamori, T. Nishi and S. Takahashi: IEEE Photon. Technol. Lett., 3(1991), 715.

(10) Y. Ohishi, T. Kanamori, J. Temmyo, M. Wada, M. Yamada, M. Shimizu, K. Yoshino, J. Hanafusa, M. Horiguchi and S. Takahashi: Electron. Lett., 27(1991), 1995. 